\title{
THE EFFECT OF COPPER ON THE ELECTRICAL ACTIVITY OF THE RABBIT MYOMETRIUM
}

\author{
T. YOSHIDA* AND G. WAGNER \\ Department of Obstetrics and Gynecology, University of Lund, Sweden, and \\ Institute of Medical Physiology B, University of Copenhagen, Denmark
}

(Received 9th May 1974)

Zipper, Medel \& Prager (1969) reported a depressive effect on the implantation rate in the rabbit with intrauterine copper wires. They postulated that the effect of the copper IUD was local rather than systemic because only minute quantities of copper were necessary to produce the antifertility effect (Zipper, Tatum, Pastene, Medel \& Rivera, 1969). The exact mechanism of the action of copper has not been clarified but the retention of the metal IUD might influence myometrial activity either by decreased or antiperistaltic activity.

In women, the presence of an IUD could provide pre-labour like uterine activity (Bengtsson \& Moawad, 1967), possibly induced by elevated blood levels of oxytocin or oxytocin-like substances (Gomez-Rogers, 1967). The present paper reports on the electrical activity of the myometrium in the rabbit after insertion of a copper IUD.

Thirteen mature female rabbits ( 3 to $5 \mathrm{~kg}$ ) were used in our experiments to study the spike burst activity recorded by three pairs of platinum electrodes, diameter $200 \mu \mathrm{m}$, implanted at 2-cm intervals on the upper, middle and lower portion of each uterine horn. The electrode leads were run under the skin and were anchored at the back of the neck. Electric potentials were fed into an a.c. amplifier of 40 to $150 \mathrm{~Hz}$ frequency limit and recorded by a pen-writing oscillograph. Nine of the thirteen rabbits received a daily intramuscular injection of $10 \mu \mathrm{g}$ oestradiol in arachidonic oil, (Leo Pharmaceutical) for 3 to 8 days before the experiment, and the remainder were in natural oestrus.

A copper wire $150 \mu \mathrm{m}$ in diameter and 6,12 or $60 \mathrm{~cm}$ long was introduced at laparotomy through a vaginal incision into the lower portion of one of the uterine horns immediately adjacent to the cervical os. The myometrial activity of each rabbit was followed for 1 to 36 days after the insertion of a copper IUD and was compared with that of the control horn (Table 1).

In seven rabbits, the small copper IUD $(150 \mu \mathrm{m} \times 6 \mathrm{~cm})$ did not, for the most part, produce any significant increase in electrical activity during an observation period of 4 to 10 days. In two rabbits receiving oestrogen, a 12-cm copper wire produced some equivocal effects, but the highest incidence of increased frequency of the spike bursts was recorded in the presence of a 60-cm copper wire. In one case, a prolonged stimulatory action was observed for a period of 8 days after the IUD was removed (Table 1).

* Present address: Department of Obstetrics and Gynecology, Jutendo University, School of Medicine 2-1-1 Hongo, Bunkyoku, Japan. 
Table 1. Effect of copper on the electrical activity of non-pregnant rabbit myometrium

\begin{tabular}{|c|c|c|c|c|c|}
\hline Experimental condition & Hormonal status & $\begin{array}{l}\text { Total no. } \\
\text { of rabbits }\end{array}$ & \multicolumn{3}{|c|}{$+\stackrel{\text { Responses* }}{\text { * }}^{\text {R }}$} \\
\hline $\begin{array}{l}\text { Copper wire (150 } \mu \mathrm{m} \text { diameter) } \\
6 \mathrm{~cm}\end{array}$ & $\begin{array}{l}\text { Natural oestrus } \\
\text { Oestrogen-treated } \dagger \\
\text { (4 to } 10 \text { days) }\end{array}$ & $\begin{array}{l}4 \\
3\end{array}$ & $\begin{array}{l}1 \\
0\end{array}$ & $\begin{array}{l}2 \\
3\end{array}$ & $\begin{array}{l}1 \\
0\end{array}$ \\
\hline $12 \mathrm{~cm}$ & $\begin{array}{l}\text { Oestrogen-treated } \\
\text { (4 to } 10 \text { days) }\end{array}$ & 2 & 1 & 1 & 0 \\
\hline 30 and $60 \mathrm{~cm}$ & $\begin{array}{l}\text { Oestrogen-treated } \\
\text { ( } 2 \text { to } 36 \text { days) }\end{array}$ & 4 & 2 & 2 & 0 \\
\hline $\begin{array}{l}\text { Platinum wire (200 } \mu \text { m diameter) } \\
22.5 \mathrm{~cm}\end{array}$ & $\begin{array}{l}\text { Oestrogen-treated } \\
\text { ( } 3 \text { to } 8 \text { days) }\end{array}$ & 2 & 0 & 2 & 0 \\
\hline $\begin{array}{l}\text { Cupric acetate } \\
30 \text { and } 60 \mathrm{mg} \\
110,180 \text { and } 200 \mathrm{mg}\end{array}$ & $\begin{array}{l}\text { Oestrogen-treated } \\
\text { ( } 1 \text { to } 29 \text { days })\end{array}$ & $\begin{array}{l}2 \\
3\end{array}$ & $\begin{array}{l}0 \\
3\end{array}$ & $\begin{array}{l}0 \\
0\end{array}$ & $\begin{array}{l}2 \\
0\end{array}$ \\
\hline $\begin{array}{l}\text { Cupric chloride } \$ \\
100 \text { and } 150 \mathrm{mg}\end{array}$ & $\begin{array}{l}\text { Oestrogen-treated } \\
\text { (8 to } 10 \text { days) }\end{array}$ & 4 & 4 & 0 & 0 \\
\hline
\end{tabular}

$*+=$ Increased, $\pm=$ unchanged and $-=$ decreased electrical activity, i.e. spontaneous spike bursts.

† Daily intramuscular injection of $10 \mu \mathrm{g}$ oestradiol in oil.

$\ddagger\left(\mathrm{GH}_{3} \mathrm{COO}\right)_{2} \mathrm{Cu} \cdot \mathrm{H}_{2} \mathrm{O}$.

$\$ \mathrm{CuCi}_{2} \cdot \mathrm{H}_{2} \mathrm{O}$.

In order to rule out the possibility that the results were due to some nonspecific effect of a foreign body, a platinum wire $(200 \mu \mathrm{m} \times 22.5 \mathrm{~cm})$ was inserted into the uterine cavity of two rabbits instead of copper wire. No change in the myometrial activity was found in the horns containing the platinum wire.

Nine rabbits treated with oestrogen received an instillation of cupric acetate or cupric chloride by constant infusion into the uterine cavity through a catheter with a sponge tip (Table 1). The compound was given in $1 \mathrm{ml}$ saline over a period of 15 to $60 \mathrm{~min}$. A physiological saline solution was infused simultaneously into the ipsilateral control horn. Instillation of 30 or $60 \mathrm{mg}$ copper salt produced a lowering of the electrical activity; instillation of amounts exceeding $100 \mathrm{mg}$, however, resulted in a decreased frequency followed by a very substantial increase in the frequency of spike bursts. Insignificant changes in electrical activity were observed in the control horn. The excitatory action of copper acetate lasted for several hours when the dose exceeded $200 \mathrm{mg}$.

Increased myometrial activity has been reported in the rat and rabbit after placing a silk thread or polyethylene foreign body in the uterine cavity (Ishihama \& Hojo, 1970). In the present study, however, a significant increase in the frequency of spike bursts occurred only after the insertion of a large copper wire or the administration of a large quantity of copper salt. These results indicate that myometrial activity in the rabbit is not affected by a minute quantity of copper, so that the antifertility effect of a copper IUD is unlikely to be due to copper-induced changes in myometrial activity.

The authors are indebted to Miss Birdie Knudsen for her technical assistance and to Professor L. Ph. Bengtsson for his interest and encouragement. This work was supported partly by a Ford Foundation Grant. 


\section{REFERENCES}

Bengtsson, L. Ph. \& Moawad, A. H. (1967) The effect of the Lippes loop on human myometrial activity. Am. 7. Obstet. Gynec. 98, 957.

Gomez-Rogers, C. (1967) The effect of intrauterine devices on lactation. Proc. 8th Int. Conf. int. plann. parent. Fedn, Santiago, Chile, Abstract No. 142.

Ishinama, A. \& Hojo, M. (1970) Myometrial activity of the uterus with intrauterine contraceptive device. Int. 7. Gynaec. Obstet. 8, 513.

Ztpper, J., Medel, M. \& Prager, R. (1969) Suppression of fertility by intrauterine copper and zinc in rabbits. Am. 7. Obstet. Gynec. 105, 529.

Zipper, J. A., Tatum, H. J., Pastene, L., Medel, M. \& Rrvera, M. (1969) Metallic copper as an intrauterine contraceptive adjunct to the "T" device. Am. F. Obstet. Gynec. 105, 1274. 